\title{
A List of the Bird-Skins obtained in South China, with Notes and Description.
}

\author{
By
}

Nagamichi Kuroda, D. Sc.

I have recently obtained 71 skins (55 species and subspecies) of birds from the Chineso collectors and taxidermists, Tang Jen-kuan (唐仁官) and his brother Tang Jui-yu (唐瑞玉), through the courty of Messrs. D. K. Kajiwara（椐原國生氏） and T. Watanabe (渡邊俊郎氏) of Shanghai. The specimens mostly came from Shanghai, Woosung and Nanking in Kiangsu, and some of them from Fooclıow in Fukien, Kwangsi (廣 西省) and Chekiang (浙江省).

Fain. CORVIDAE.

1. Corvus coronoides colonorum Swinhoe.

1 juv., Foochow (福州), Fukien (福建省) xii. 1928. Wing $305 \mathrm{~mm}$.

2. Corvus torquatus Lesson.

1 ad., Foochow, xii. 1928.

3. Coloeus dauricus dauricus (Pallas).

1 ad. (dark form: neglectus), Shanghai (上海), Kiangsu (江蕉省) iii. 1929.

4. Pica pica sericea Gould.

1 ad., Shanghai, ii. 1929.

5. Cyanopica cyana swinhoei Hartert.

1 ad., Shanghaj, ii. 1929.

6. Urocissa erythrorhyncha erythrorhyncha (Boddaert).

1 ad., Foochow, xii. 1928. 
Fam. STURNIDAE.

7. Aethiopsar cristatellus cristatellus (Swinhoe).

1 ad., Foochow, xi. 1928.

8. Spodiopsar sericeus (Gmelin).

1 ad., Shanghai, xii. 1928.

Fam. ORIOLIDAE.

9. Oriolus chinensis indicus Jerdon.

1 ad, Shanghui, vi. 1929.

Fam. FRINGILLIDAE.

10. Eophona migratoria pulla Penard.

1 q ad., Shanghai, ii. 1929. Wing 103.5, culmen 21.5 $\mathrm{mm}$.

11. Passer montanus saturatus Stejneger.

1 o ad., Shanghai, ii. 1929. Entire culmen 10.5, height of bill $7 \mathrm{~mm}$.

Fam. PARIDAE.

12. Parus major artatus Thayer \& Bangs.

2 ads., Shanghai, ii. 1929. Wing 66, 67.5; tail $60.5,61$ $\mathrm{mm}$.

I have referred these two specimens to artatus rather than to commixtus. (Cf. Hartert, Vüg. pal. Faun., Nachtrag I, 1923, p. 38 and La Touche, Handb. B. Eastern China, Part I, 1925, pp. $23-25)$.

13. Aegithalos caudatus glaucogularis (Moore).

1 ad., Shanghai, iv. 1929.

Fam. LANIIDAE.

14. Lanius sehach schach Linnaeus.

1 ad., Shanghai, iii. 1929. 
Fam. BRACHYPODIDAE.

15. Pycnonotus sinensis sinensis (Gmelin).

1 ad., Shanghai, iii. 1929 . Wing $88.5 \mathrm{~mm}$.

Dr. Stresemann (J. f. O., 1923, p. 363) has separated a form from "Wusung" (Woosung) near Shanghai under the name of septentrionalis and has stated that the length of wing in the latter form varies from 92 to $97 \mathrm{~mm}$. instead of $82-91$ mm.as in sinensis. My specimen, however,appears to belong to the latter form than to the former (see wing length).

Fam. CAMPOPHAGIDAE or PERICROCOTIDAE (Baker).

16. Pericrocotus speciosus fohkiensis Baker.

1 ad. and 1 o ad., Kwangsi (廣西), xi. 1927. Wing, f 103 ; q $98 \mathrm{~mm}$.

It is recorded only from Kwangtung and Fukien, so that this is probably the first recurd for this form obtained in Kwangsi. It is slightly larger form than typical speciosus ("wing 92-101" - according to Baker). The length of wing of fohkiensis measured by La Touche is as follows :"wing, § 100-106, \& 99-102."

Fam. DICRURIDAE.

17. Dicrurus macrocercus cathoecus Swinhoe.

1 ad., Foochow, iii. 1928.

Fam. ARTAMIDAE.

18. Artamus fuscus Vieillot.

1 ad., Kwangsi, xi. 1928.

Fam. MUSCICAPIDAE.

19. Terpsiphone paradisi incei (Gould). 
1 \& (white plumage), v. 1929 and 1 \& (reddish-brown plumage), vi. 1929.

Both obtained in Shanghai. Wing 88 (white of), 92 (brown \&).

Fam. SYLVIIDAE.

20. Acanthopnenste nitidus plumbeitarsus (Swinhoe).

1 ad., Shanghai, iii. 1929.

This specimen has two distinct wing bars and should be referrable to Baker's saturatus, but I am inclined to consider that the opinion of Dr. Hartert (Vög. pal. Faun., pp. 511, 512) seems to be correct on the wing bars which change according to seasons by abrasion of the white tips of the feathers in summer dress.

21. Horornis cantans canturiaus (Swinhoe).

1 of ad., Shanghai, iv. 1929.

Fam. TURDIDAE.

22. Turdus hortulorum Sclater.

1 t ad., Shanghai, iii. 1929.

23. Turdus merula mandarinus Bonaparte.

1 ad., Foochow, xi. 1928.

Fam. ENICURIDAE.

24. Enicuras leschenanlti sinensis Gould.

1 ad, Foochow, xii. 1928 . Wing 109.5 ; tail 156 ; tarsus 30 ; entire culmen 25 ; outermost tail-feathers $37 \mathrm{~mm}$. shorter than the second.

Fam. HIRUNDINIDAE.

25. Hirundo rustica gutturalis Scopoli.

1 s ad., Shanghai, v. 1929. 
Fam. EURYLAEMIDAE.

26. Psarisomus dalhousiae dalhousiae (Jameson).

$1 \mathrm{ad}$., Kwangsi (廣西), xi. 1928. Wing $100.5 \mathrm{~mm}$.

There are 3 forms of the species recognized as follows :-

P. d. dalhosiae (Jameson)- "Himalaya Mountains, Assam, Manipur, Cachar, Burma." (Hartert).

P. d. psittacinus (Müller)-Sumatra.

P. d. borneensis Hartert.-Kina Balu, Borneo.

I have no record of this species found in S. China though it is recorded from Lao Kay, Tonkin (wing $95 \mathrm{~mm}$.). 'The length of wing in the present specimen measures $100.5 \mathrm{~mm}$. and the coloration of body richer and darker quite equal to the Himalayan and the typical form. Mr. Baker gives the measurements of wing from several localities as follows :-

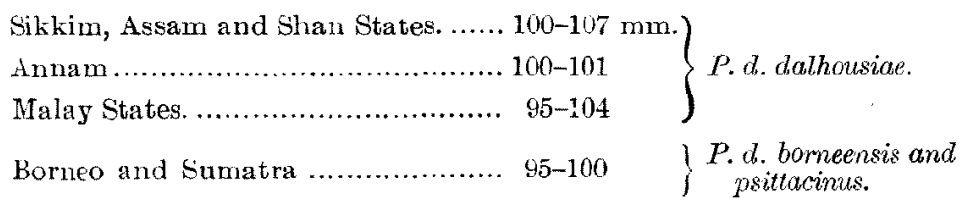

Fam. ALCEDINIDAE.

27. Ceryle lugubris guttulata Stejneger.

1 s ad. and 1 o ad., Foochow, xii. 1928.

28. Alcedo atthis bengalensis Gmelin.

1 f ad., Shangha, i. 1929. Wing $71 \mathrm{~mm}$.

29. Halcyon smyruensis fusca (Boddaert).

1 ad., Foochow, xii. 1928. Wing $124 \mathrm{~mm}$.

Fam. PICIDAE.

30. Dryobates hardwickii scintilliceps (Swinhoe).

1 of ad., Nanking, Kiangsu, ii. 1929. Wing 98.5; tail $66 \mathrm{~mm}$.

31. Dryobates major cabanisi (Malherbe). 
1 of ad. and 1 q ad, Nanking, Kiangsu, ii. 1928.

Dr. G. D. Wilder has given me two specimens of this form from "Tunghsien (通具), Hopei" (i. and iii. 1929). I have compared them with one skin from Makden, S. Manchuria, and those of Dr. Rensch's measurements, which results are as follows :-

\begin{tabular}{ccc}
\multicolumn{3}{c}{ Measured by Kuroda. } \\
Mukden & Wing & Entire culm. \\
$1 f$ & 128 & 29 \\
Tunghsien & & \\
$1 \hat{\delta}$ & 132.5 & 32.5 \\
$1 \delta$ & 126.5 & 35.5 \\
Nanking & & \\
$1 \hat{\sigma}$ & 125 & 33 \\
1 \& & 125 & 31
\end{tabular}

Measured by Dr. Rensch.

\begin{tabular}{|c|c|c|}
\hline Peking & Wing & Culmen \\
\hline $2 \hat{\partial} \hat{\partial}$ & 128 & 31 \\
\hline 19 & 133 & 39 \\
\hline \multicolumn{3}{|c|}{ "Bannwald" } \\
\hline $1 \hat{\theta}$ & 128 & 29.5 \\
\hline 19 & 127 & 26 \\
\hline \multicolumn{3}{|c|}{$\begin{array}{l}\text { "Schangtaiwan, } \\
\text { Kwanjientschou" }\end{array}$} \\
\hline 13 & 131 & 31 \\
\hline 4 오오 & $128-130$ & $26-28$ \\
\hline
\end{tabular}

The two $\delta$ skins from Tunghsien have their eulmens seem to be longer than others and one of the males (N. Kuroda Coll. No. 12346) has outer tail-feathers nearly unbarred! (probably an individual variation). The another male (No. 12347) las the scapulars distinctly and subterminaly tipped with white and with narrow black apical margins to the feathers. The last charncter shows the connection between typical major and cabanisi*

32. Dryobates major mandarinus (Malherbe).

1 \& ad. Foochow, Fukien, xi. 1928. Wing 135.5; entire culmen $32 \mathrm{~mm}$.

This skin seems to belong to the South Chinese form with longer wing and much darker underparts than any other specimens before me.

* I perfectly agree with $D r$. Rensch who has united both major and cabanisi into one species. 
I take this opportuniby to describe an apparently new form of the Great Spotted Woodpecker from N. China :--

Dryobates major renschi, subsp. nov.

Diagnosis- - Similar to dark phase of seoulensis from Korea, but bill longer and broader, wing also a trifle longer, white aren of edge of wing much purer white with a few obscure dusky bars, white spots on wing distinctly larger and outer tail-feathers have a few spots of dark brown instead of very thickly banded as in seoulensis.

Measurements-- 우 ad. (type), wing 123.5, tail 83.5, tarsns 21, entire culmen 31 , width of upper mandible at base 13 , height of mandibles at front of nasal plumes $8 \mathrm{~mm}$.

Type from Prov. Chihli, N. China, March, 1915. Collected by a Clinese. Presented by Dr. G. D. Wilder of Peking. N. Kuroda Coll. no. 11265.

Remarks. - The new form is very distinct from cabinisi-group and it also differs from tscherskiz and breviostris (both compared). Possibly Dr. Rensch (Abh. u. Ber. d. Mus. f. Tierk. u. Volkerk. \$n Jresden, 1923, Bd. XVI, Nr. 2, p. 37) is quite right to consider that winter birds at Peking which have white or grey markings on scapulars are all came lown from northern districts. My specimen also seems to be the same, but it is distinguished from any known forms of major.

Named in honour of Dr. Bernhard Rensth of the Zoological Mrnsenm in Berlin.

Fam. GUCULIDAE.

33. Hierococcyx sparverioides (Vigors).

1 ad., Nanking, vi. 1929.

34. Centropus sinensis sinensis (Stephen).

1 juv., Fooehow, xii. 1927, Wing 197, tail 278, tarsus 59 , entire culmen $39 \mathrm{~mm}$.

Fam. STRIGIDAE.

35. Otus bakkamoena glabripes (Swinhoo).

1 ad., Foochow, xii. 1927.

Fam. FALCONIDAE. 
36. Cerchneis tinnunculus interstinctus (McClelland).

$1 \delta$ ad., Foochow, viii. 1928. Wing 237, tail $162 \mathrm{~mm}$.

Fam. ANATIDAE.

37. Dendronessa galericulata (Linnaeus).

1 of ad., Chekinng (浙江省), xii. 1928. Wing 228, tail 104.5 , tarsus 38 , exposed culmen $26.5 \mathrm{~mm}$.

The present specimen examined by me is as follows :-

(i) The central stripe in the elongated feathers of the neck pure white; (ii) the black posterior border of the elongated innermost tertial $4 \mathrm{~mm}$. in width; (iii) the border of the upper mandible adjacent to the sides of the face inclined anteriorly; and (iv) the length of wing only $228 \mathrm{~mm}$.

I have examined a large series of the species from Japan, Korea, Formosa and China, and came to the conclusion that Clark's brmnescens from Kjusiu and Shanghai (Proc. Biol. Soc. Wash., XXVII, p. 87, 1914) is undoubtedly a synonym of galericulata. The results of my investigation are appearing in my "Avifauna of the Riu Kiu Islands," 1925, pp. 141-143.

38. Nettapus coromandelianus coromandelianus (Gmelin).

2 of of, Nanking, vi. 1929. Wing 151.5 (no. 12271), 160 (no. 12270).

No. 12271 has nearly withont green metallic colour to the wing-coverts and without white patch on primaries. Tips of secondaries with white ( $\delta$ in second year ?).

Fam. COLUMBIDAE.

39. Oenopopelia tranquebarica hamilis (Temminck).

1 of ad., Shanghai, v. 1929.

Fam. CHARADRIIDAE.

40. Charadrius leschenaultii leschenaultii Lesson.

1 \& ad. in breeding plumage, Woosung, Kiangsu, iv. 
1929.

41. Eupoda asiatica veredus (Could).

1 ad. (hiem.), Woosung, v. 1929.

42. Pluvialis apricarius fulvus (Gmelin).

1 ad. (aest.), Woosung, v. 1929.

43. Microsarcops cinereus (Blyth).

2 ads., Woosung, ii. 1929.

44. Pelidna alpina sakbalina (Vieillot).

1 f (hiem.-aest.), Woosung, iv. 1929.

45. Calidris canutus rogersi (Mathews).

1 ad. (aest.), Woosung; v. 1929.

46. Calidris tenuirostris (Horsficld).

2 ads. (aest.), Woosung, v. 1929.

47. Eurynorhynchus pygmacus (Linnaeus.)

3 ads. (hiem. \& hiem.-aest.), Woosung, v. 1929.

48. Pseudoglottis guttifer (Nordmann).

1 ad. (aest.), Woosung, v. 1929. Wing 172, tail 66.5, tarsus 44.5 , middle toe \& cluw 34 , exposed cuimen 53.5 mm.

49. Tringa totanus eurbinus (Oberholser).

Syn. terrignotae Col. \& Mrs. Meinertzhagen (1926).

1 ad. (aest.), Woosung, v. 1929. Wing $159.5 \mathrm{~mm}$.

50. Tringa ochropus Linnacus.

1 ad., Woosung, v. 1929.

51. Rhyacophilus glareolus (Gmelin).

1 ad., Woosung, v. 1929.

52. Mesoscolopax minutus (Gould).

4 ads., Woosung, end of April, 1929.

Fam. PARRIDAE.

53. Hydrophasianus chirurgus (Scopoli).

2 ads., Woosung, vi. 1929. 
64

Fam. RALLIDAE.

54. Porzana pusilla pusilla (Pallas).

1 \& ? (ad.), Woosung, v. 1929.

Fam. PHASIANIDAE.

55. Coturnix coturnix japonica Temminek \& Schlegel.

$1 \mathrm{~s}$ ad., Shanghai, iii. 1929. Wing $93 \mathrm{~mm}$. 